\title{
Shlomo Venezia, Sonderkommando. W piekle komór gazowych, przeł. Krystyna Szeżyńska-Maćkowiak, Prószyński i S-ka, przy współpracy z Państwowym Muzeum Auschwitz-Birkenau, Warszawa 2009
}

Nieliczni członkowie Sonderkommando, którym udało się przeżyć obóz, często czekali wiele lat, aby opowiedzieć swoją historię. Zmuszeni w KL Auschwitz-Birkenau do pracy w krematoriach, milczeli po wojnie, bojąc się oskarżenia o kolaborację z Niemcami podczas eksterminacji narodu żydowskiego ${ }^{1}$. Dyskusje nad etycznym aspektem ich postępowania podczas Zagłady wzbudzały wielokrotnie równie dużo emocji i kontrowersji, jak podobne debaty dotyczące zachowań więźniów funkcyjnych w obozach koncentracyjnych czy przedstawicieli Judenratów w gettach. Badacze Holokaustu, ale też byli więźniowie nierzadko oskarżali członków Sonderkommando o brutalność wobec ludzi idących do komór gazowych oraz o czerpanie korzyści z ich śmierci. Do niezrozumienia i potępienia, z którym spotykali się na zewnątrz, często dochodził własny strach przed konfrontacją z trudną przeszłością i przed oskarżeniem o kłamstwo ze strony tych, którym ich opowieści wydawały się niewyobrażalne².

W latach osiemdziesiątych i dziewięćdziesiątych stosunek naukowców - ale i opinii publicznej - do tej grupy więźniów stał się przychylniejszy i mniej jednostronny niż w okresie wcześniejszym. Członkowie „Sonderkommando wyszli $\mathrm{z}$ ukrycia i przestali taić swoją tożsamość. Zaczęli występować w audycjach radiowych, a nawet w filmach, oraz udzielać wywiadów dla prasy”3. Wtedy także zdecydował się złożyć swoje świadectwo grecki Żyd włoskiego pochodzenia, Shlomo Venezia. Zaczął on opowiadać o swojej przeszłości podczas wizyty w Muzeum Auschwitz-Birkenau w 1992 r. W 2006 r. odbył serię spotkań z Béatrice Prasquier, których efektem stała się książka o jego obozowych doświadczeniach, przetłumaczona na język polski i wydana w 2009 r.

Sonderkommando. W piekle komór gazowych to ujęta w ramy wywiadu rzeki opowieść Venezii o jego przedwojennym życiu, niemieckiej okupacji Grecji, pracy

${ }^{1}$ Nazwy Sonderkommando zaczęto używać w KL Auschwitz-Birkenau we wrześniu 1942 r. Określała ona grupę więźniów zatrudnionych przy bezpośredniej eksterminacji ludność żydowskiej. Wcześniej używano jej wprawdzie w Chełmnie nad Nerem, ale odnosiła się zarówno do więźniów, jak i do esesmanów pracujących „przy urządzeniach masowej zagłady”, por. G. Greif, ...płakaliśmy bez łez... Relacje bytych więźniów żydowskiego Sonderkommando z Auschwitz, przeł. J. Kapłon, Warszawa-Oświęcim 2007, s. 23.

${ }^{2} \mathrm{Na}$ temat moralnej oceny postępowania członków Sonderkommando w obozie ibidem, s. 74-92.

${ }^{3}$ Ibidem, s. 98. 
w krematorium III w Birkenau, pobycie w kilku niemieckich obozach i wreszcie o końcu wojny i siedmioletnim leczeniu ciężkiej choroby płuc.

Pierwsza część książki to świadectwo tego, jak żyła i w jaki sposób została zniszczona kilkudziesięciotysięczna społeczność sefardyjskich Żydów w Grecji. Venezia, urodzony w 1923 r. w Salonikach, mimo swojego włoskiego pochodzenia i obywatelstwa oraz wynikających z tego przywilejów (pomoc ambasady i żołnierzy), cała młodość spędził wśród biedoty żydowskiej w tym mieście. Z perspektywy dziecka opisuje świat zamkniętej i nieświadomej swojego przyszłego losu społeczności: „Byliśmy głodni, zaprzątały nas troski dnia codziennego, nie mieliśmy czasu zastanawiać się nad przyszłością. Dlatego Niemcy bez żadnych kłopotów deportowali Żydów z Grecji”" . Mimo pomocy ambasady włoskiej i przeprowadzki do Aten, Venezii nie udało się uniknąć deportacji. Został wysłany do KL Auschwitz-Birkenau w jednym transporcie z bratem w kwietniu $1944 \mathrm{r}$.

Najważniejszy i najdłuższy fragment książki stanowi relacja greckiego Żyda z pracy w Sonderkommando. Po przybyciu do obozu stracił on matkę i dwie młodsze siostry, jednak z tego, co działo się wokół, zdał sobie sprawę dopiero, kiedy razem z innymi Grekami został wybrany do pracy w krematoriach. Chociaż jego głównym zajęciem było tam obcinanie włosów zamordowanym kobietom, musiał także wyciągać ciała z komory gazowej, trzymać ludzi, którym esesmani strzelali w tył głowy, kruszyć ludzkie kości czy nadzorować ofiary w rozbieralni. Venezii udało się przetrwać w obozie, ponieważ przybywające nieustannie w połowie $1944 \mathrm{r}$. nowe transporty z węgierskimi Żydami były przyczyną wstrzymania przez Niemców regularnych selekcji wśród więźniów komanda specjalnego. Po buncie Sonderkommando (7 października 1944 r.) Venezia został przeniesiony z krematorium III do krematorium II i uczestniczył w rozbiórce budynków, w których znajdowały się komory gazowe. W czasie ewakuacji obozu przyłączył się do jednej z grup opuszczających Auschwitz i przez następne cztery miesiące tułał się po niemieckich kacetach. Odzyskał wolność w Ebensee, jednak z powodu ciężkiej choroby płuc musiał leczyć się przez wiele lat.

Wartość historyczna świadectwa Shlomo Venezii jest niezaprzeczalna - stanowi źródło informacji na temat sposobu postępowania z ofiarami, pracy w krematoriach, topografii miejsc, wyglądu budynków czy buntu Sonderkommando - chociaż większość prezentowanych przez niego faktów była już wcześniej znana historykom dzięki wspomnieniom, zeznaniom, wywiadom czy relacjom (znalezionym przy krematoriach) więźniów z komanda specjalnego ${ }^{5}$. Tym, co najbardziej poruszające w tej książce, co stanowi o jej wartości dla czytelnika, jest więc nie tyle jej faktogra-

${ }^{4}$ S. Venezia, Sonderkommando. W piekle komór gazowych, przeł. K. Szeżyńska-Maćkowiak, Warszawa 2009, s. 27.

${ }^{5}$ Zob. Wśród koszmarnej zbrodni. Rękopisy członków Sonderkommando, „Zeszyty Oświęcimskie” 1971, nr 2, specjalny; C. Lanzmann, Shoah, przeł. M. Bieńczyk, Koszalin 1993; G. Greif, op. cit.; M. Nyiszli, Bytem asystentem doktora Mengele: wspomnienia lekarza z Oświęcimia, przeł. T. Olszański, Oświęcim 2000; Z. Gradowski, Wolny człowieku wiedz, że to jest ogień z piekła..., brak nazwiska tłumacza, „Pro Memoria” 2006, nr 25. 
ficzna czy historyczna zawartość, ile możliwość przyjrzenia się próbie, którą podjął Venezia - zrozumienia tego, co wydarzyło się w jego przeszłości i zmierzenia się z nią. Mając świadomość, że tamta rzeczywistość była - jak napisał Primo Levi szarą strefą „o konturach trudnych do określenia”, stanowiącą ,przeszkodę dla naszej potrzeby jasnego osądu" ", oraz że kryteria ustanowione do jej oceny przez tych, którzy znajdują się na zewnątrz, są nieodpowiednie, postanawia on opowiedzieć nam o obrazie przeszłości widzianym „oczami świadka” patrzącego z kilkudziesięcioletniej perspektywy. Venezia sam sobie zadaje najtrudniejsze pytania: Co zrobiłby, gdyby jemu samemu rozkazano zabijać? Dlaczego nie popełnił samobójstwa, kiedy zorientował się, jaką pracę będzie musiał wykonywać? Tłumaczy czytelnikowi motywy, które kierowały nim, kiedy zmusił starą, zawstydzoną kobietę do zdjęcia ubrania w rozbieralni, co czuł, kiedy dotykał martwych ciał bądź gdy odprowadzał swoich bliskich do komory gazowej. Wreszcie próbuje odeprzeć, niesłuszne zresztą, zarzuty o kolaborację czy zmierzyć się z krążącymi po wojnie pogłoskami o postępowaniu w obozie więźniów z Sonderkommando. Świadectwo greckiego Żyda, który w momencie, kiedy dostał się do obozu, miał 21 lat, a dzisiaj jest człowiekiem u kresu swojej drogi życiowej, zasługuje na uwagę wrażliwych i zainteresowanych Zagładą czytelników, chociażby dlatego, że po latach milczenia i cichej konfrontacji z oskarżeniami i niedowierzaniem, po życiu naznaczonym, jak pisze, „chorobą ocalonych”, zdecydował się szczerze i uczciwie opisać swoją przeszłość. Takiego wysiłku nie wolno nam zignorować, niezależnie od tego, jak bardzo niewyobrażalna i trudna jest dla nas opowieść o tamtej rzeczywistości.

Marta Zawodna

${ }^{6}$ P. Levi, Pogrą̇eni i ocaleni, przeł. S. Kasprzysiak, Kraków 2007, s. 46. 